\title{
Concentrations of luteinizing hormone and ovulatory responses in dairy cows before timed artificial insemination ${ }^{1}$
}

\author{
S. L. Pulley, ${ }^{* 2}$ D. H. Keisler, $†$ and J. S. Stevenson ${ }^{* 3}$ \\ *Department of Animal Sciences and Industry, Kansas State University, Manhattan 66506-0201 \\ †Division of Animal Sciences, University of Missouri, Columbia 65211
}

\begin{abstract}
The objective was to determine the incidence of $\mathrm{LH}$ surges and ovulatory responses in lactating dairy cows enrolled in a timed artificial insemination (TAI) program. Cows were assigned randomly to 2 presynchronization treatments: (1) Pre10 $(\mathrm{n}=37): 2$ injections of $\mathrm{PGF}_{2 \alpha}$ (PG; PG-1 and PG-2) $14 \mathrm{~d}$ apart (Presynch); or (2) PG-3-G ( $\mathrm{n}=33)$ : one 25-mg injection of PG (PrePG) administered $3 \mathrm{~d}$ before a $100-\mu \mathrm{g}$ GnRH injection (Pre-GnRH). Ten days after PG-2 or Pre-PG, all cows were enrolled in a 7-d Ovsynch TAI program [injection of GnRH (GnRH-1) $7 \mathrm{~d}$ before PG (PG-3) and GnRH (GnRH-2) administered at either 56 or $72 \mathrm{~h}$ after PG-3; TAI at $72 \mathrm{~h}$ ]. Blood was collected to determine $\mathrm{LH}$ at (1) Pre-GnRH: 48 to $80 \mathrm{~h}$ after PG-2 and hourly from 72 to $78 \mathrm{~h}$ (Pre-GnRH at $72 \mathrm{~h}$ ); (2) GnRH-1: 0 to 6 $\mathrm{h}$ after GnRH-1; and (3) GnRH-2: 48 to $80 \mathrm{~h}$ after PG-3 and hourly from 56 to $62 \mathrm{~h}$ or 72 to $78 \mathrm{~h}$ for cows injected with GnRH-2 at 56 or $72 \mathrm{~h}$ after PG-3, respectively. Ovaries were scanned and pregnancy per TAI (P/AI) was diagnosed 31 and $61 \mathrm{~d}$ post-TAI by transrectal ultrasonography. The Pre-GnRH injection increased the incidences of LH surges (100 vs. 43\%) and ovulation (91 vs. 60\%) and subsequent concentrations of progesterone in PG-3-G cows compared with Pre10 cows, respectively. Seven days later, incidence of ovulation (48 to $62 \%$ ) and occurrence of LH surges $(100 \%)$ did not differ between treatments after GnRH1. In contrast, $\mathrm{LH}$ concentrations and area under the LH curve of Pre10 cows were greater than that of PG3-G cows because progesterone was greater in PG-3-G than in Pre10 cows $(4.6 \pm 0.4$ vs. $2.8 \pm 0.4 \mathrm{ng} / \mathrm{mL})$, respectively. Concentrations of LH did not differ after GnRH-2 at either 56 or $72 \mathrm{~h}$; however, 1 cow receiving GnRH-2 at $56 \mathrm{~h}$ and 3 cows at $72 \mathrm{~h}$ had early spontaneous LH surges before GnRH-2. Ovulation was
\end{abstract}

Received February 16, 2015.

Accepted May 23, 2015.

${ }^{1}$ Contribution number 15-258-J from the Kansas Agricultural Experiment Station, Manhattan 66506.

${ }^{2}$ Current address: Arkansas State University, Jonesboro, AR 72467.

${ }^{3}$ Corresponding author: jss@k-state.edu suppressed overall in 210 blood collection windows in cows with elevated progesterone concentrations. When progesterone was $<1 \mathrm{ng} / \mathrm{mL}$ after either PG-2 or PG-3 injections, GnRH-induced LH surges occurred in more than $90 \%$ of cows, and incidence of ovulation exceeded $80 \%$. Pregnancy per AI tended to differ for PG-3-G (56.7\%) compared with Pre10 (37.8\%) and for $56 \mathrm{~h}(54.5 \%)$ compared with $72 \mathrm{~h}(38.2 \%)$, with the Pre10-72 h treatment combination producing less than half $(22.2 \%)$ the pregnancies compared with all other treatment combinations. Furthermore, in these same cows, post-TAI luteal tissue volume tended to be compromised. We conclude that incidences of GnRHinduced LH surges and ovulation are suppressed in cows with elevated progesterone, possibly contributing to some loss in P/AI in TAI programs.

Key words: luteal function, luteinizing hormone, ovulation, presynchronization, progesterone

\section{INTRODUCTION}

Synchronization of ovulation to allow for timed artificial insemination (TAI) has become one of the most adopted reproductive technologies by dairy producers (Caraviello et al., 2006; Moeller et al., 2010). The most commonly used TAI programs in the dairy industry are variants of the original Ovsynch protocol [Pursley et al., 1998; injection of GnRH $7 \mathrm{~d}$ before and $48 \mathrm{~h}$ after $\mathrm{PGF}_{2 \alpha}(\mathbf{P G})$ with TAI $16 \mathrm{~h}$ following the last $\mathrm{GnRH}$ injection]. Presynchronizing the estrous cycles of cows improves pregnancy per AI (P/AI) compared with cows starting Ovsynch at random stages of the estrous cycle (Moreira et al., 2001; El-Zarkouny et al., 2004; Navanukraw et al., 2004). Improved P/AI resulting from presynchronization programs before Ovsynch has been associated with synchronizing the majority of estrous cycles to d 5 through 12, which improved ovulation incidence to the first GnRH injection of Ovsynch and resulting $\mathrm{P} / \mathrm{AI}$ compared with cows treated at random stages of the estrous cycle (Vasconcelos et al., 1999).

A standard PG-presynchronization protocol involves 2 PG injections given $14 \mathrm{~d}$ apart, with initiation of the 
Ovsynch protocol 12 d later $(14 \times 12$; Moreira et al., 2001). Other intervals between the second PG Presynch injection and the onset of Ovsynch, $14 \mathrm{~d}(14 \times 14$; Navanukraw et al., 2004), 11 d $(14 \times 11$; Galvão et al., 2007), and $10 \mathrm{~d}(14 \times 10$; Stevenson et al., 2012), have been investigated. The $14 \times 11$ Presynch program increased P/AI compared with Presynch 14 × 14 (Galvão et al., 2007).

Other presynchronization programs including PG and GnRH (PG-3-G: Peters and Pursley, 2002; Stevenson et al., 2012; Stevenson and Pulley, 2012; or G-6-G: Bello et al., 2006; Ribeiro et al., 2011) and application of a nonbreeding Ovsynch-like treatment before the TAI Ovsynch program (Double Ovsynch; (Souza et al., 2008; Ribeiro et al., 2011; Herlihy et al., 2012) has generally increased $\mathrm{P} / \mathrm{AI}$ compared with Ovsynch alone or with other Presynch-PG programs. Presynchronization programs that include $\mathrm{GnRH}$ improved ovulatory responses before Ovsynch (Stevenson et al., 2012), increased the proportion of cows having progesterone concentrations $\geq 1 \mathrm{ng} / \mathrm{mL}$ at GnRH-1 (Herlihy et al., 2012; Stevenson et al., 2012; Ayres et al., 2013), increased the number of CL in anovular cows at GnRH1 (Herlihy et al., 2012; Stevenson et al., 2012), and increased P/AI during summer (Stevenson and Pulley, 2012) compared with current Presynch-PG programs.

Despite wide application of TAI programs, relatively little is known about the characteristics of LH concentrations or incidences of LH surges in association with the PG-induced luteolysis and GnRH injections associated with these TAI programs. Concentrations of LH in response to either 50 or $100 \mu \mathrm{g}$ of different $\mathrm{GnRH}$ products have been reported (Souza et al., 2009). One product tended to release less LH after both doses and induce fewer ovulations than the other 3 products in diestrous lactating dairy cows treated $7 \mathrm{~d}$ after TAI (Souza et al., 2009). Furthermore, this same GnRH product stimulated fewer ovulations and less LH release in beef heifers compared with another GnRH product (Martinez et al., 2003). In virgin heifers and lactating dairy cows treated with 2 injections of PG $11 \mathrm{~d}$ apart with GnRH administered $72 \mathrm{~h}$ after the last PG injection, LH surges were detected in all females, with $39 \%$ being induced by $\mathrm{GnRH}$ and $61 \%$ occurring spontaneously (Lucy and Stevenson, 1986). It is not known what proportion of LH surges occur before or after GnRH injections in various TAI programs. In addition, the relationship of the characteristics of LH concentrations associated with each GnRH injection and the steroid milieu had not been determined when this study was initiated during autumn 2011.

Thus, this study was designed to determine the incidence of spontaneous and predictable GnRH-induced
LH surges (peak LH magnitude, area under the LH secretion curve, and time to peak LH concentration) and subsequent ovulation in lactating dairy cows enrolled in a TAI program preceded by presynchronization of estrous cycles. Ancillary measures of progesterone, estradiol, and ovarian structures were also made to confirm our previous findings in response to the same 2 treatments (Stevenson et al., 2012) as well as improved $\mathrm{P} / \mathrm{AI}$ in a previous large 4-herd study (Stevenson and Pulley, 2012).

\section{MATERIALS AND METHODS}

\section{Cows, Housing, and Diets}

The current studies were approved by the Kansas State University Institutional Animal Care and Use Committee. Lactating Holstein cows were enrolled at calving from September 2011 through March 2012 at the Kansas State University Dairy Teaching and Research Center. Cows were considered to be structurally sound and were housed individually in a tiestall barn equipped with feed bunks, automatic waterers, and stall mats covered with wood shavings. Cows were moved to a double- 6 herringbone parlor and milked thrice daily. Cows were fed individually ad libitum twice daily at 0630 and $1600 \mathrm{~h}$. A TMR calculated to meet nutrient requirements for lactating dairy cows producing $50 \mathrm{~kg}$ of 3.5\% milk (NRC, 2001) consisted of alfalfa hay, corn silage, soybean meal, whole cottonseed, corn or milo grain, corn gluten feed, vitamins, and minerals. Cows were evaluated daily for health status by trained farm personnel.

\section{Experimental Design and Treatments}

A total of 70 cows were enrolled in 10 weekly clusters according to calving date and were assigned randomly within lactation number $(1$ vs. $\geq 2)$ to receive 1 of 2 presynchronization treatments (Figure 1). The first presynchronization treatment $(\mathbf{P G}-\mathbf{3 - G} ; \mathrm{n}=33$; Stevenson and Pulley, 2012; Stevenson et al., 2012) consisted of a 25-mg injection (i.m.) of $\mathrm{PGF}_{2 \alpha}$ (PrePG; $5 \mathrm{~mL}$ Lutalyse Sterile Solution, Zoetis, Florham Park, NJ) 3 d before a 100- $\mu$ g (i.m.) injection of GnRH (Pre-GnRH; $2 \mathrm{~mL}$ Factrel, Zoetis). The second treatment (Pre10; $\mathrm{n}=37)$ was timed so that the second of 2 (administered $14 \mathrm{~d}$ apart) 25-mg injections (i.m.) of PG (PG-2; $5 \mathrm{~mL}$ Lutalyse Sterile Solution, Zoetis) was administered on the same day as the Pre-PG injection of the PG-3-G treatment (Figure 1). Beginning $10 \mathrm{~d}$ after PG-2 (Pre10) or Pre-PG (PG-3-G), all cows were enrolled in a 7-d Ovsynch programs in which they 


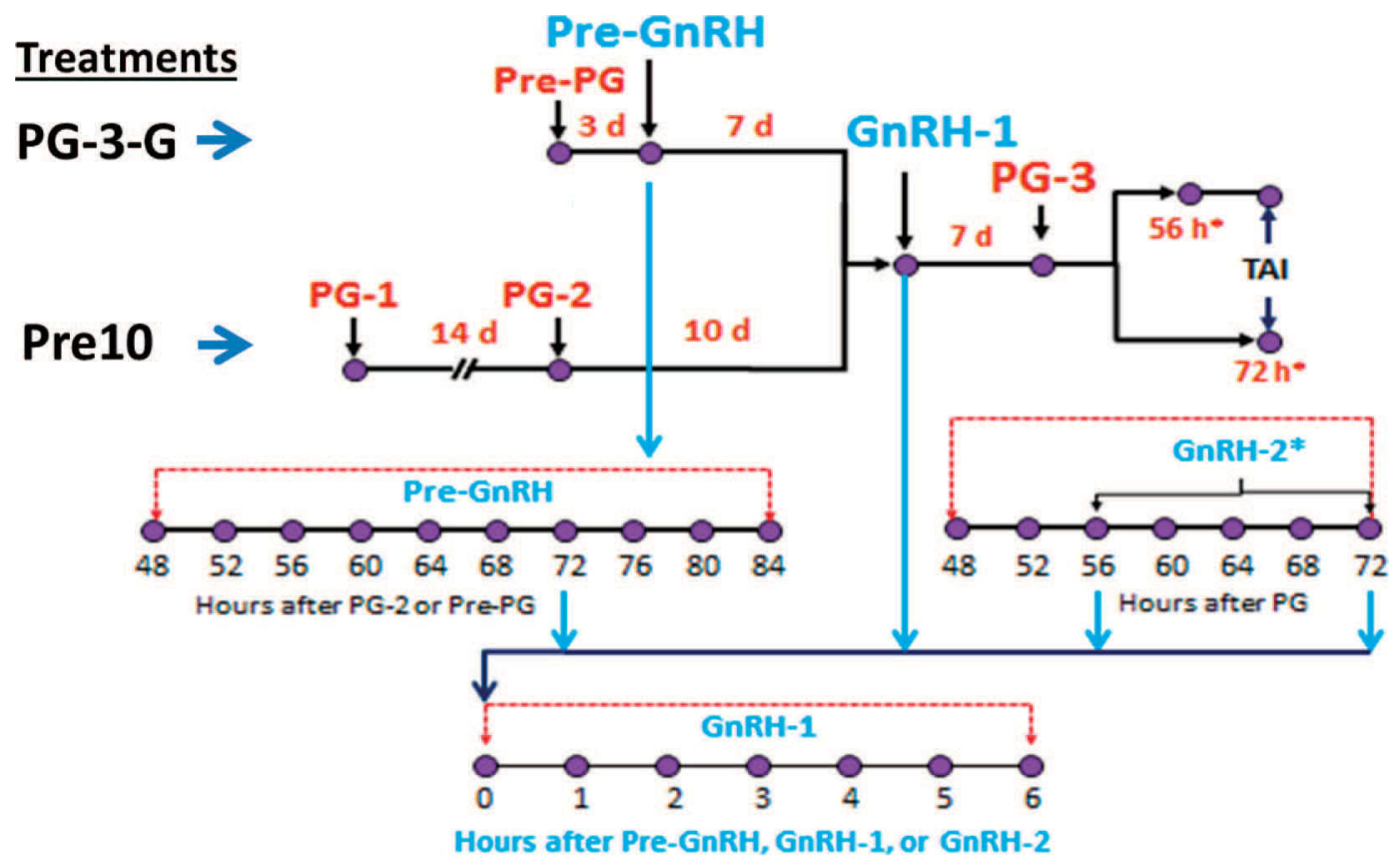

Figure 1. Experimental design of treatments and blood sampling. At calving, lactating dairy cows were assigned randomly to 1 of 2 presynchronization protocols: PG-3-G [25-mg injection of PGF $_{2 \alpha}$ (Pre-PG) and then $100 \mu \mathrm{g}$ of GnRH (Pre-GnRH) $3 \mathrm{~d}$ later, followed by enrollment into the Ovsynch program $7 \mathrm{~d}$ later] or Pre10 [25-mg injection of $\mathrm{PGF}_{2 \mathrm{a}}$ (PG-1 and PG-2) administered $14 \mathrm{~d}$ apart, with the Ovsynch protocol initiated $10 \mathrm{~d}$ later]. The Ovsynch protocol is initiated with an injection of GnRH (GnRH-1) followed $7 \mathrm{~d}$ with an injection of PG with a second GnRH injection (GnRH-2) administered at either 56 or $72 \mathrm{~h}$ after PG. Blood was collected to determine LH concentrations at (1) Pre-GnRH: every $4 \mathrm{~h}$ from 0 to $80 \mathrm{~h}$ after PG-2 and hourly from 72 to $78 \mathrm{~h}$ (Pre-GnRH injected at $72 \mathrm{~h}$ ); (2) GnRH-1: hourly from 0 to $6 \mathrm{~h}$ after GnRH-1; (3) GnRH-2: every $4 \mathrm{~h}$ from 0 to $80 \mathrm{~h}$ after PG and either hourly from 56 to $62 \mathrm{~h}$ (GnRH-2 injected at $56 \mathrm{~h}$ ) or hourly from 72 to $80 \mathrm{~h}$ (GnRH-2 injected at $72 \mathrm{~h}$ ). Color version available online.

received (i.m.) $100 \mu \mathrm{g}$ of $\mathrm{GnRH}$ (GnRH-1; $2 \mathrm{~mL}$ of Factrel, Zoetis), followed in $7 \mathrm{~d}$ by $25 \mathrm{mg}$ of PG (PG-3; $5 \mathrm{~mL}$ Lutalyse Sterile Solution, Zoetis). Approximately one-half of the cows in each presynchronization treatment received the second $100 \mu \mathrm{g}$ of GnRH (GnRH-2; $2 \mathrm{~mL}$ of Factrel, Zoetis) at either 56 or $72 \mathrm{~h}$ after PG-3. All cows were inseminated at $72 \mathrm{~h}$ after PG-3. Therefore, 4 treatment-time combinations were formed at 56 $\mathrm{h}$ after PG-3: PG-3-G-56 ( $\mathrm{n}=16)$; PG-3-G-72 ( $\mathrm{n}=$ $17)$; Pre10-56 ( $\mathrm{n}=19)$; and Pre10-72 ( $\mathrm{n}=18)$. Treatment injections were staggered within cluster so that all cows were inseminated on the same day of the week.

Body condition scores $(1=$ thin and $5=$ fat; Ferguson et al., 1994) were determined and assigned $7 \mathrm{~d}$ before the initiation of the TAI Ovsynch program (Figure 1). Cows were at a median of 68 DIM $(68.4 \pm 0.7$; mean \pm SE) at TAI. Frozen-thawed semen from multiple sires was used.

\section{Ovarian Structures and Ovulation}

Transrectal ovarian scans were conducted in all cows by ultrasonography $(7.5-\mathrm{MHz}$ linear-array transducer, Aloka 500V; Corometrics Medical Systems Inc., Wall- ingford, CT) to record diameter and map location of follicles $\geq 5 \mathrm{~mm}$ and any corpus luteum (CL) present at Pre-GnRH, GnRH-1, PG-3, GnRH-2, and 6 d post-TAI, when the diameter of all luteal structures was measured (Figure 1). A map of each ovary was drawn with the position and size of all follicles and the location of each CL, which allowed for evaluation of ovulatory responses to Pre-GnRH, GnRH-1, and GnRH-2. Follicle diameter was determined by averaging the width and height of each follicle using the internal electronic calipers of the ultrasound machine. During the ultrasound exam before administration of GnRH-2, the presence of anechoic fluid in the uterine lumen was recorded (bioassay of potential estrus and effects of estradiol).

Pregnancy diagnosis was conducted by transrectal ultrasonography on d 31 and 61 after TAI. A positive pregnancy outcome required the presence of anechoic uterine fluid and a CL $\geq 25 \mathrm{~mm}$ in diameter or anechoic uterine fluid and the presence of a viable embryo with a visible heartbeat. Cows that displayed estrus and were re-inseminated before the first pregnancy diagnosis were considered not pregnant to TAI unless later ultrasonography found re-inseminated cows to be pregnant to TAI. 


\section{Procedures and Blood Sample Collections}

Blood samples were collected by placement of an indwelling jugular catheter or, in the event of jugular catheter failure, by puncture of caudal vessels into evacuated tubes (Vacutainer; Becton, Dickinson and Co., Franklin Lakes, NJ). Cows were fitted with a guide wire-style jugular catheter (Mila International Inc., Erlanger, KY). Under local anesthesia (lidocaine hydrochloride; Agri Laboratories Ltd., St. Joseph, MO), a size-10 scalpel blade was used to make a 0.5-inch incision to initially breech the skin and allow access to the jugular vein. A 45-cm-long guide wire was threaded through the needle. The catheter $(20 \mathrm{~cm})$ was then strung onto the wire and guided into the jugular vein. Catheters were flushed twice daily and after each blood collection with a sterile saline solution containing 3.5\% sodium citrate to prevent clotting. All blood samples were placed on ice upon collection and stored at $5^{\circ} \mathrm{C}$, and then transported to the laboratory and stored at $5^{\circ} \mathrm{C}$ for approximately 8 to $16 \mathrm{~h}$ before serum was harvested by centrifugation at $1,000 \times g$ for $15 \mathrm{~min}$ in a refrigerated centrifuge. Blood sera were frozen and stored at $-20^{\circ} \mathrm{C}$ until progesterone, estradiol, and $\mathrm{LH}$ concentrations were determined by RIA.

\section{Hormone Concentrations}

Concentrations of LH were measured in the following blood sera samples. Beginning with $0 \mathrm{~h}$ after Pre-PG or PG-2, and PG-3, blood was collected every $4 \mathrm{~h}$ from 48 through $84 \mathrm{~h}$. Additional samples were collected hourly (0 to $6 \mathrm{~h}$ ) after each $\mathrm{GnRH}$ injection (Pre-GnRH or a comparable time for Pre10 cows, GnRH-1, GnRH-2 at either 56 or 72 h; Figure 1). All sera samples for LH concentration were measured in triplicate and analyzed by liquid-phase double-antibody RIA (Atkins et al., 2008). Sera were assayed in triplicate $(100 \mu \mathrm{L})$ in 6 assays. Pooled bovine sera assayed in quadruplicate at $25,40,60,100,175,200$, and $300 \mu \mathrm{L}$ averaged $9.8 \pm 0.3$ $\mathrm{ng} / \mathrm{mL}$ and paralleled the standard curve. Intra- and interassay CV averaged 4.9 and $5.7 \%$, respectively.

Peak LH concentrations and time to LH peak were determined by examining individual LH plots of each 6-h window of hourly blood collection. To determine if an LH surge occurred, a baseline mean and standard deviation were calculated for the 7 samples ( 0 through $6 \mathrm{~h}$ ) after deleting the 2 largest concentrations. An "LH surge" was defined to occur when the largest LH concentration exceeded the mean of the remaining baseline by $2 \mathrm{SD}$. Surges were then defined as GnRH-induced or having occurred spontaneously before, during, or after the beginning of the 6-h sampling window in the absence of GnRH. Exceptions to the previous procedure occurred in a few of the $210 \mathrm{LH}$ window plots when a surge was obvious but failed to meet the defined criteria. Area under the curve (AUC) for LH concentration was calculated as the sum of trapezoid areas, in which Cp2 was the LH serum concentration of a sample taken at time 2 (t2) and Cp1 was the LH concentration of a sample taken at time $1(\mathrm{t} 1)$. The following formula was used to calculate the area under the LH curve during the 6-h window after each GnRH injection:

$$
\begin{gathered}
\mathrm{AUC}=\Sigma[(\mathrm{Cp} 1+\mathrm{Cp} 2) / 2 \times(\mathrm{t} 2-\mathrm{t} 1)+\ldots \\
+(\mathrm{Cpn}+\mathrm{Cpn}) / 2 \times(\mathrm{tn}+1-\mathrm{tn})] .
\end{gathered}
$$

Concentrations of progesterone in blood serum were measured in samples collected at 0 and $72 \mathrm{~h}$ after PG-2 or Pre-PG and at 0 and $60 \mathrm{~h}$ after PG-3 (Figure 1). Additional sera samples were pooled during the 6-h sampling windows at each $\mathrm{GnRH}$ injection (PreGnRH, GnRH-1, and GnRH-2; Figure 1) by taking 0.1 $\mathrm{mL}$ of serum from each sample and combining into a single aliquot, which was then assayed for progesterone concentration. All serum samples for progesterone concentration were measured in duplicate and analyzed by direct quantitative (nonextracted) RIA using CoatA-Count progesterone kits (cat. no. TKPG; Siemens Medical Solutions Diagnostics, Los Angeles, CA) previously validated for bovine serum (Stevenson et al., 2012). Cows having luteolysis (CL regression) must have had serum progesterone $\geq 1 \mathrm{ng} / \mathrm{mL}$ at $\mathrm{PG}-2$ or Pre-PG and $<0.5 \mathrm{ng} / \mathrm{mL} 72 \mathrm{~h}$ later or $\geq 1 \mathrm{ng} / \mathrm{mL}$ at PG-3 and $<0.5 \mathrm{ng} / \mathrm{mL} 60 \mathrm{~h}$ later. Assay sensitivity of the progesterone RIA was $0.047 \pm 0.004 \mathrm{ng} / \mathrm{mL}$, and intra- and interassay coefficients of variation for 12 assays were 3.4 and $5.1 \%$, respectively, for a pool of bovine serum that averaged $2.8 \pm 0.04 \mathrm{ng} / \mathrm{mL}$.

Concentrations of estradiol were measured in duplicate by RIA (Stevenson, 2011) in samples collected at $0,24,36,48,60$, and $72 \mathrm{~h}$ after PG-3 administration (Figure 1). Assay sensitivity was $1.1 \pm 0.4 \mathrm{pg} / \mathrm{mL}$, and intra- and interassay coefficients of variation for 2 assays were 2.6 and $5.5 \%$, respectively, for a pool of bovine serum that averaged $6.3 \pm 0.3 \mathrm{pg} / \mathrm{mL}$.

\section{Statistical Analyses}

The experiment was a completely randomized design with 2 treatments (PG-3-G vs. Pre10), with cows balanced for lactation number (1 vs. $\geq 2$ ) until $56 \mathrm{~h}$ after PG-3 when the timing of GnRH-2 occurred at either 56 or $72 \mathrm{~h}$ after PG-3. From $56 \mathrm{~h}$, the experimental design became a $2 \times 2$ factorial arrangement of 4 treatments (PG-3-G-56, PG-3-G-72, Pre10-56, or Pre10-72); cow was the experimental unit. Unless otherwise specified, 
all values were expressed as least squares means \pm SEM.

Various binomial characteristics and responses to hormonal injections ( $\mathrm{GnRH}$ and $\mathrm{PG}$ ) were analyzed by logistic regression using the LOGISTIC procedure of SAS (SAS Institute Inc., Cary, NC). These responses included the proportions of cows having luteolysis (defined previously), LH surges, uterine fluid, and ovulation (single or $>1$ ). The initial model included fixed effects of treatment (PG-3-G vs. Pre10), lactation number ( 1 vs. $\geq 2)$, and $\operatorname{BCS}(<2.75$ vs. $\geq 2.75)$. The final model produced by backward stepwise selection of independent variables entered or retained in the model was based on the Wald statistic $(P>0.10)$. In general, for variables assessed $56 \mathrm{~h}$ after GnRH-3, the model included permutations of treatment and time of GnRH3 to form 4 treatments. These models first examined the main effects of treatment and GnRH time. When a significant interaction was detected by ANOVA, the model included all 4 permutations of the main effects.

Analyses of serum LH concentrations, follicle diameter, CL number, LH peak, and area under the LH curve were performed using the MIXED procedure of the SAS program (SAS Institute Inc.). The model included fixed effects of treatment, lactation number, and BCS. The model for the comparisons of area under the curve of LH profiles for GnRH-2 used a model that included treatment, GnRH-2 time (56 vs. $72 \mathrm{~h}$ ), circulating progesterone concentrations ( $<0.5$ vs. $\geq 0.5$ or $<1.0$ vs. $\geq 1.0 \mathrm{ng} / \mathrm{mL}$ ), circulating estradiol concentration $(<2.0$ vs. $\geq 2.0 \mathrm{pg} / \mathrm{mL})$, treatment $\times$ time, treatment $\times$ progesterone concentration cut-point, treatment $\times$ estradiol concentration cut-point, and all 3-way interactions.

Repeated measurements, including serum concentrations of estradiol $(0,24,36,48,60$, and $72 \mathrm{~h}$ after PG-3) and LH (hourly LH concentrations during $6 \mathrm{~h}$ after $\mathrm{GnRH}$ ), were analyzed as a split-plot design in the MIXED procedure in SAS. The model included fixed effects of treatment, day, treatment $\times$ day, lactation number, and BCS. Cow within treatment was treated as a random variable and was the split-plot error term for testing treatment differences.

Pregnancy outcomes at $\mathrm{d} 31$ and 61 post-TAI and pregnancy losses were analyzed by SAS procedure LOGISTIC using the initial model of treatment, lactation number, their interaction, technician, sire, and BCS.

\section{RESULTS}

\section{PG-2}

Before PG-2 administration, circulating concentrations of progesterone and proportions of cows having progesterone concentrations $\geq 1 \mathrm{ng} / \mathrm{mL}$ did not differ between treatments (Table 1 ). The proportion of cows having luteolysis after PG-2 or Pre-PG also did not differ between treatments (Table 1).

\section{Pre-GnRH}

Before Pre-GnRH administration, circulating concentrations of progesterone, the proportion of cows with progesterone concentrations $<1 \mathrm{ng} / \mathrm{mL}$, the number of CL per cow, the proportion of cows with CL, and the diameters of the largest and second-largest follicles (PG-3-G: $11.2 \pm 4.2$ vs. Pre10: $11.4 \pm 4.4 \mathrm{~mm}$ ) did not differ between treatments (Table 2).

Patterns of LH concentration during the 6-h blood collection period are shown in Figure 2A. As expected, cows receiving the Pre-GnRH injection had greater $(P$ $<0.01)$ LH concentrations at 1 and $2 \mathrm{~h}$ than Pre10 cows receiving no GnRH. The proportion of cows with

Table 1. Progesterone concentrations (LSM \pm SEM) and responses to presynchronization injection of PG-2 or Pre-PG

\begin{tabular}{lccc}
\hline & \multicolumn{2}{c}{ Treatment $^{1}$} \\
\cline { 2 - 3 } Item & PG-3-G & Pre10 & P-value \\
\hline Progesterone $^{2}(\mathrm{ng} / \mathrm{mL})$ & $3.2 \pm 0.5$ & $3.5 \pm 0.5$ & 0.657 \\
Response $[\%(\mathrm{no} / \mathrm{no})]$ & & & \\
Progesterone $^{2} 1 \mathrm{ng} / \mathrm{mL}^{3}$ & $72.7(24 / 33)$ & $64.9(24 / 37)$ & 0.772 \\
Luteolysis $^{4}$ & $79.1(19 / 24)$ & $87.5(21 / 24)$ & 0.872 \\
\hline
\end{tabular}

${ }^{1} \mathrm{PG}-3-\mathrm{G}=$ injection of $\mathrm{PGF}_{2 \alpha}$ (Pre-PG) administered at the same time as PG-2 followed in $3 \mathrm{~d}$ by Pre-GnRH injection, which was administered $7 \mathrm{~d}$ before onset of Ovsynch; Pre10 $=2$ injections of $\mathrm{PGF}_{2 \alpha} 14 \mathrm{~d}$ apart $(\mathrm{PG}-1$ and PG-2) with PG-2 administered $10 \mathrm{~d}$ before onset of Ovsynch (see Figure 1).

${ }^{2}$ Progesterone concentrations before PG-2 or Pre-PG.

${ }^{3}$ Proportion of cows having progesterone concentrations $\geq 1 \mathrm{ng} / \mathrm{mL}$ before PG-2 or Pre-PG.

${ }^{4}$ Luteolysis was determined by changes in progesterone concentration between PGF-2 $(\geq 1 \mathrm{ng} / \mathrm{mL})$ and $72 \mathrm{~h}$ later $(<0.5 \mathrm{ng} / \mathrm{mL})$. 
Table 2. Ovarian responses at or after Pre-GnRH [injection of $\mathrm{PGF}_{2 \alpha}$ (Pre-PG) 3 d before injection of GnRH]

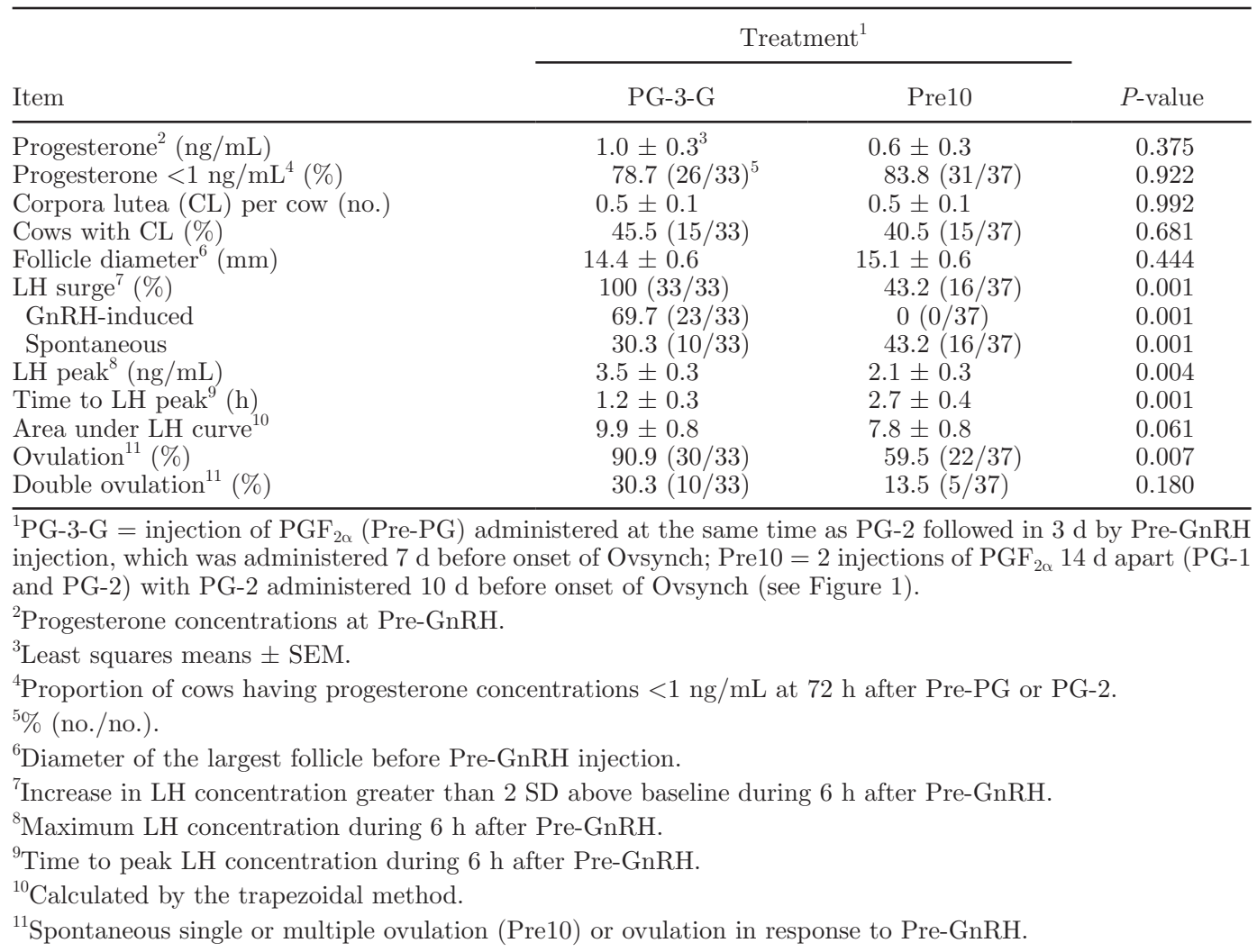

an LH surge after Pre-GnRH was greater $(P<0.001)$ in PG-3-G cows than in Pre10 cows, in which only spontaneous LH surges could occur (Table 2). Although mean LH peak concentration was greater $(P=0.004)$ in PG-3-G cows and time to peak LH occurred earlier $(P=0.001)$ than in Pre10 cows, area under the LH curve only tended $(P=0.061)$ to be greater for PG-3-G than for Pre10 cows. Concentrations of progesterone and the number of CL (0 vs. $1+$ ) had no effect on LH peak concentrations after Pre-GnRH. The proportion of cows ovulating after Pre-GnRH was greater $(P=$ 0.007) in PG-3-G than in Pre10 (Table 2).

\section{GnRH-1}

The proportion of cows with progesterone concentrations $\geq 1 \mathrm{ng} / \mathrm{mL}$, number of CL per cow, and the proportion of cows with a $C L$ were greater $(P \leq 0.015)$ for PG-3-G than for Pre10 cows at GnRH-1 (onset of the Ovsynch protocol; Table 3). Diameters of the largest (Table 3) and second-largest follicles (PG-3-G: $10.7 \pm$ 0.9 vs. Pre10: $9.7 \pm 0.9$ ) before GnRH-1 administration did not differ between treatments.

In the face of greater $(P<0.001)$ progesterone concentrations at GnRH-1, concentrations of LH were lower $(P<0.01)$ at 1,2 , and $3 \mathrm{~h}$ after $\mathrm{GnRH}-1$ in $\mathrm{PG}-$ $3-\mathrm{G}$ cows than in Pre10 cows (Figure $2 \mathrm{~B}$ ). The number of CL per cow did not affect peak LH concentrations; however, cows with progesterone concentrations $\geq 1 \mathrm{ng} /$ $\mathrm{mL}$ had decreased $(P=0.001) \mathrm{LH}$ peak concentrations after GnRH-1 compared with cows having progesterone concentrations $<1.0 \mathrm{ng} / \mathrm{mL}(2.2 \pm 0.2$ vs. $4.1 \pm 0.4 \mathrm{ng} /$ $\mathrm{mL}$, respectively).

All cows had GnRH-induced LH surges, but LH peak concentration was greater in Pre10 than in PG-3-G cows, whereas time to LH peak did not differ (Table $3)$. Incidence of single or double ovulation also did not differ between treatments (Table 3).

\section{PG-3}

Although the proportion of cows with $\geq 1$ CL was greater $(P=0.053)$ in $\mathrm{PG}-3-\mathrm{G}$ cows than in Pre10 cows before $\mathrm{PG}-3$, none of the other ovarian characteristics assessed before PG-3 differed between treatments (Table 4). Mean concentrations of progesterone were approximately $5 \mathrm{ng} / \mathrm{mL}$, the proportion of cows with progesterone concentrations $\geq 1 \mathrm{ng} / \mathrm{mL}$ exceeded $93 \%$, and the number of CL ranged from 1.7 to 1.9 regardless of treatment. No differences were detected in follicle 

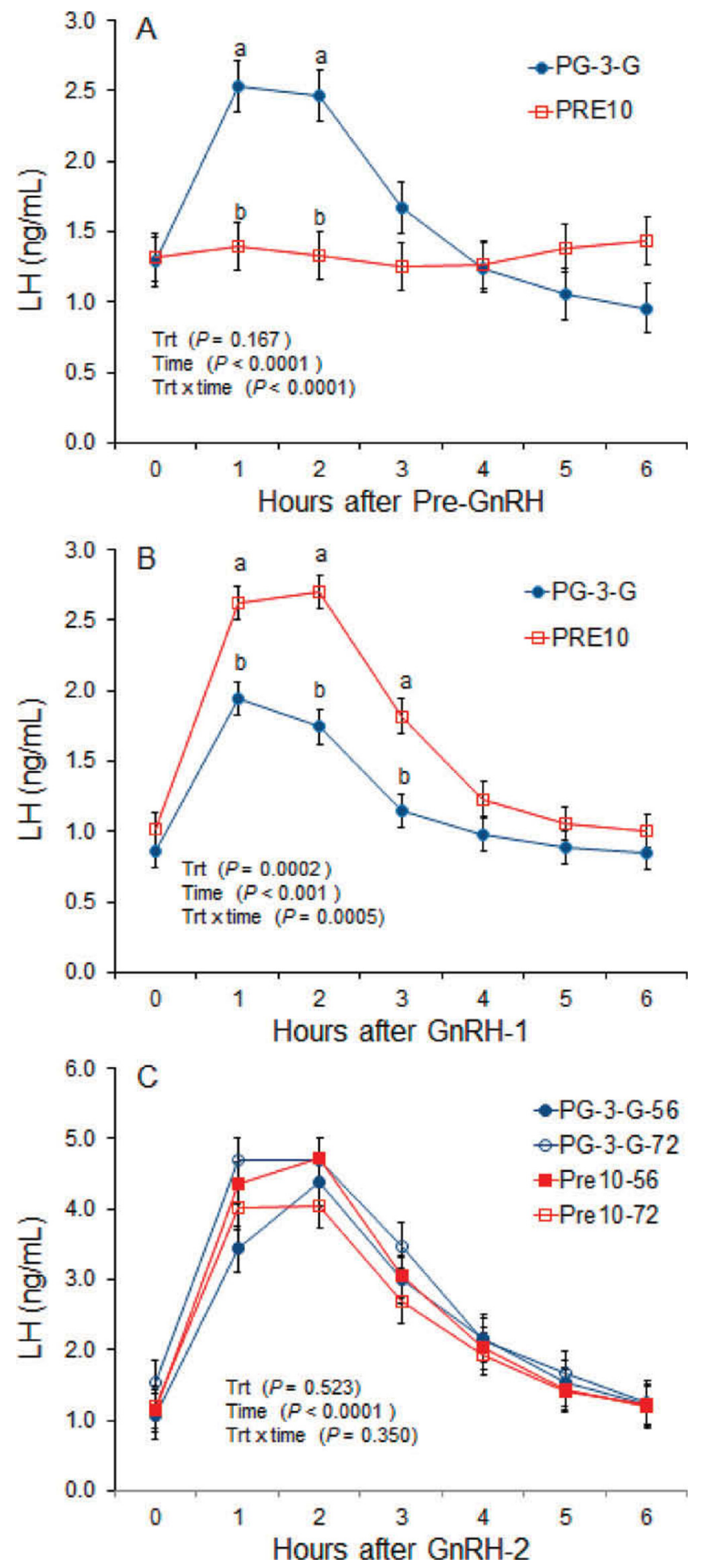

Figure 2. Pattern of mean $( \pm \mathrm{SE})$ serum LH concentrations during $6 \mathrm{~h}$ after Pre-GnRH (A) and GnRH-1 (B) in cows in presynchronization treatments PG-3-G $(\mathrm{n}=33)$ or Pre10 $(\mathrm{n}=37)$; see Figure 1 for treatment definitions. Pattern of mean serum LH concentrations during $6 \mathrm{~h}$ after $\mathrm{GnRH}-2$ (C) according to presynchronization treatments and time of GnRH-2 administration: PG-3-G-56 ( $\mathrm{n}=16)$, PG-3-G-72 $(\mathrm{n}=17)$, Pre10-56 $(\mathrm{n}=19)$, or Pre10-72 $(\mathrm{n}=18)$. Treatment means within hour having different letters $(\mathrm{a}, \mathrm{b})$ differ $(P<0.05)$. Color version available online. size, estradiol concentrations before PG-3, or incidence of luteolysis after PG-3 between treatments.

\section{GnRH-2}

Diameter of the largest follicle at $48 \mathrm{~h}$ after PG-3, concentrations of progesterone, and the proportion of cows with progesterone $<1 \mathrm{ng} / \mathrm{mL}$ at $60 \mathrm{~h}$ did not differ between treatments (Table 5). Of the 70 cows with LH surges, 4 had spontaneous LH surges: 1 PG-3-G-56 cow (64 to $68 \mathrm{~h}$ ); 2 PG-3-72 cows (68 to $72 \mathrm{~h}$ ); and 1 Pre10-72 cow (64 to $68 \mathrm{~h}$ ) after PG-3.

After GnRH-2 administration, LH concentrations increased $(P<0.001)$ to peaks at 1 to $2 \mathrm{~h}$ before steadily decreasing to basal concentrations by $6 \mathrm{~h}$ (Figure 2C). Neither treatment nor time had any detectable effects on LH concentrations during the 6-h sampling period after GnRH-2. Furthermore, none of the other LH characteristics ( $\mathrm{LH}$ peak concentration, time to LH peak, or area under the curve) differed between treatments (Table 5). Tendencies were detected for time to LH peak between treatments $(P=0.114$; earlier peaks for Pre10 than PG-3-G cows) and between times $(P=$ 0.124; earlier peaks for cows injected at 72 than $56 \mathrm{~h}$ after PG-3).

Ovulatory incidence did not differ among treatmenttime combinations; only 7 of 70 cows did not ovulate, and 7 of 64 cows ovulated $>1$ follicle (Table 5 ).

Concentrations of estradiol did not differ among treatments until $72 \mathrm{~h}$ after PG-3 (Figure 3), when concentrations were greater $(P<0.05)$ in $\mathrm{PG}-3-\mathrm{G}$ than in Pre10 cows. The presence of uterine fluid during the ultrasound examination at $48 \mathrm{~h}$ after PG-3 was not influenced by treatment (PG-3-G $=27.3 \%$ vs. Pre10 $=43.2 \%)$. Cows with estradiol concentration $\geq 2.0 \mathrm{pg} /$ $\mathrm{mL}$ at $48 \mathrm{~h}$ after PG-3, however, had a greater $(P=$ 0.04 ) incidence of uterine fluid than cows with estradiol concentrations $\leq 2.0 \mathrm{pg} / \mathrm{mL}[87.0 \%(20 / 23)$ vs. $17.4 \%$ $(4 / 23)]$, respectively.

\section{Ovulatory Response and Progesterone}

Ovulatory responses to GnRH-induced or spontaneous LH surges in the presence of a functional or regressing CL are summarized in Table 6. Overall incidence of ovulation was $73.3 \%$ and did not differ between treatments. Of opportunities to detect LH surges in the 37 Pre10 cows (no Pre-GnRH injection was given), LH surges were not detected in 21 cows, but 9 of the 21 cows ovulated. In the remaining 16 cows, 13 of 16 cows ovulated. During the Pre-GnRH period, more cows ovulated in which an LH surge was detected compared with no detected LH surge (87.8 vs. $42.9 \% ; P=0.042)$. Incidence of ovulation did not 
Table 3. Ovarian responses at or after GnRH-1 (100 $\mu \mathrm{g}$ of GnRH to initiate a 7-d Ovsynch program)

\begin{tabular}{|c|c|c|c|}
\hline \multirow[b]{2}{*}{ Item } & \multicolumn{2}{|c|}{ Treatment $^{1}$} & \multirow[b]{2}{*}{$P$-value } \\
\hline & PG-3-G & Pre10 & \\
\hline Progesterone $^{2}(\mathrm{ng} / \mathrm{mL})$ & $4.6 \pm 0.4^{3}$ & $2.8 \pm 0.4$ & $<0.001$ \\
\hline Progesterone $\geq 1 \mathrm{ng} / \mathrm{mL}^{4}(\%)$ & $100(33 / 33)^{5}$ & $78.4(29 / 37)$ & 0.015 \\
\hline Corpora lutea (CL) per cow (no.) & $1.5 \pm 0.1$ & $0.9 \pm 0.1$ & 0.005 \\
\hline Cows with CL (\%) & $97.0(32 / 33)$ & $70.3(26 / 37)$ & 0.003 \\
\hline Follicle diameter ${ }^{6}(\mathrm{~mm})$ & $13.9 \pm 0.7$ & $13.4 \pm 0.7$ & 0.991 \\
\hline LH surge $^{7}(\%)$ & $100(33 / 33)^{8}$ & $100(37 / 37)$ & - \\
\hline GnRH-induced & $100(33 / 33)$ & $100(37 / 37)$ & - \\
\hline Spontaneous & $0(0 / 33)$ & $0(0 / 37)$ & - \\
\hline LH peak ${ }^{8}(\mathrm{ng} / \mathrm{mL})$ & $2.1 \pm 0.2$ & $2.8 \pm 0.2$ & 0.039 \\
\hline Time to $\mathrm{LH}$ peak $^{9}(\mathrm{~h})$ & $1.3 \pm 0.1^{7}$ & $1.4 \pm 0.1$ & 0.575 \\
\hline Area under LH curve ${ }^{10}$ & $7.4 \pm 0.7$ & $10.0 \pm 0.7$ & 0.008 \\
\hline Ovulation $^{11}(\%)$ & $48.5(16 / 33)$ & $62.2(23 / 37)$ & 0.315 \\
\hline Double ovulation $^{11}(\%)$ & $6.7(2 / 33)$ & $20.0(6 / 37)$ & 0.238 \\
\hline
\end{tabular}

${ }^{1} \mathrm{PG}-3-\mathrm{G}=$ injection of $\mathrm{PGF}_{2 \alpha}$ (Pre-PG) administered at the same time as PG-2 followed in $3 \mathrm{~d}$ by Pre-GnRH injection, which was administered $7 \mathrm{~d}$ before onset of Ovsynch; Pre10 $=2$ injections of $\mathrm{PGF}_{2 \alpha} 14 \mathrm{~d}$ apart $(\mathrm{PG}-1$ and PG-2) with PG-2 administered $10 \mathrm{~d}$ before onset of Ovsynch (see Figure 1).

${ }^{2}$ Progesterone concentrations at GnRH-1.

${ }^{3}$ Least squares means \pm SEM.

${ }^{4}$ Proportion of cows having progesterone concentrations $\geq 1 \mathrm{ng} / \mathrm{mL}$ at GnRH-1.

$5 \%$ (no./no.).

${ }^{6}$ Diameter of the largest follicle before GnRH-2 injection.

${ }^{7}$ Increase in LH concentration greater than $2 \mathrm{SD}$ above baseline during $6 \mathrm{~h}$ after GnRH-1.

${ }^{8}$ Maximum LH concentration during $6 \mathrm{~h}$ after GnRH-1.

${ }^{9}$ Time to peak LH concentration during $6 \mathrm{~h}$ after GnRH-1.

${ }^{10}$ Calculated by the trapezoidal method.

${ }^{11}$ Single or double ovulation in response to GnRH-1.

differ between treatments after GnRH-1 or GnRH-2. < 0.001) incidence of ovulation - to nearly $68 \%$ of that During 210 blood collection periods, cows with elevated in cows with low concentrations of progesterone $(0.2 \pm$ progesterone (3.3 to $4.5 \pm 0.2 \mathrm{ng} / \mathrm{mL}$ ) had reduced ( $P \quad 0.1 \mathrm{ng} / \mathrm{mL}$; Table 6$)$.

Table 4. Ovarian responses at or after PG-3 injection (25 $\mathrm{mg}$ of $\left.\mathrm{PGF}_{2 \alpha}\right)$

\begin{tabular}{|c|c|c|c|}
\hline \multirow[b]{2}{*}{ Item } & \multicolumn{2}{|c|}{ Treatment $^{1}$} & \multirow[b]{2}{*}{$P$-value } \\
\hline & PG-3-G & Pre10 & \\
\hline Progesterone $^{2}(\mathrm{ng} / \mathrm{mL})$ & $5.1 \pm 0.4^{3}$ & $4.6 \pm 0.4$ & 0.442 \\
\hline Progesterone $^{4}(\%)$ & $93.9(31 / 33)^{5}$ & $94.6(35 / 37)$ & 0.726 \\
\hline Corpora lutea (CL) per cow & $1.9 \pm 0.2$ & $1.7 \pm 0.1$ & 0.329 \\
\hline Cows with CL (\%) & $100(33 / 33)$ & $89.2(33 / 37)$ & 0.053 \\
\hline Follicle diameter ${ }^{6}(\mathrm{~mm})$ & $12.4 \pm 0.6$ & $12.2 \pm 0.6$ & 0.774 \\
\hline Estradiol $^{7}(\mathrm{pg} / \mathrm{mL})$ & $1.5 \pm 0.6$ & $2.4 \pm 0.6$ & 0.303 \\
\hline Luteolysis $^{8}(\%)$ & $96.7(30 / 31)$ & $91.4(32 / 35)$ & 0.369 \\
\hline
\end{tabular}

${ }^{1} \mathrm{PG}-3-\mathrm{G}=$ injection of $\mathrm{PGF}_{2 \alpha}$ (Pre-PG) administered at the same time as PG-2 followed in $3 \mathrm{~d}$ by Pre-GnRH injection, which was administered $7 \mathrm{~d}$ before onset of Ovsynch; Pre10 $=2$ injections of $\mathrm{PGF}_{2 \alpha} 14 \mathrm{~d}$ apart (PG-1 and PG-2) with PG-2 administered $10 \mathrm{~d}$ before onset of Ovsynch (see Figure 1).

${ }^{2}$ Progesterone concentrations at PG-3 administration.

${ }^{3}$ Least squares means \pm SEM.

${ }^{4}$ Proportion of cows having progesterone concentrations $\geq 1 \mathrm{ng} / \mathrm{mL}$ before PG-3.

$5 \%$ (no./no.).

${ }^{6}$ Diameter of the largest follicle at PG-3.

${ }^{7}$ Estradiol concentrations at PG-3.

${ }^{8}$ Progesterone $(\geq 1 \mathrm{ng} / \mathrm{mL})$ at PG-3 decreased to $<0.5 \mathrm{ng} / \mathrm{mL}$ by $60 \mathrm{~h}$ after PG-3. 


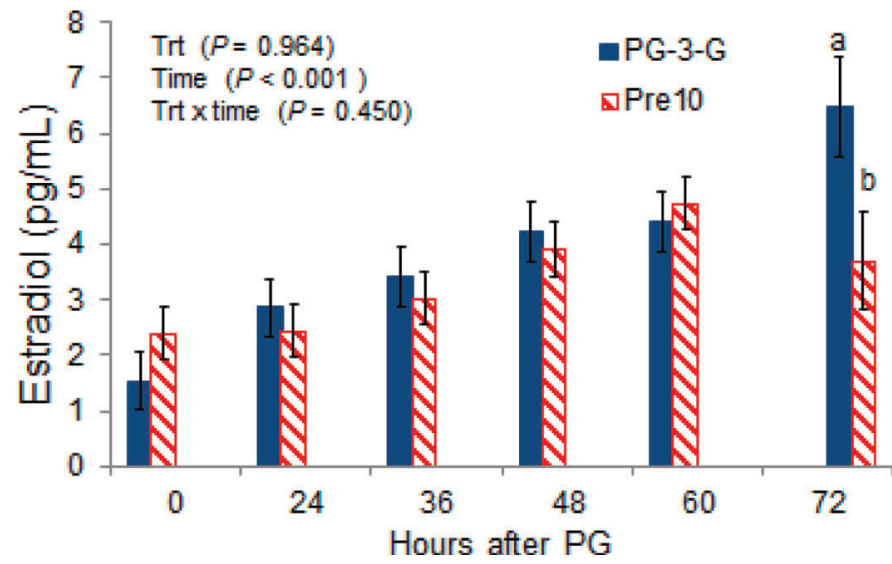

Figure 3. Least squares mean $( \pm \mathrm{SE})$ serum estradiol concentrations for PG-3-G ( $\mathrm{n}=33$ ) or Pre10 $(\mathrm{n}=37)$ cows treated with GnRH-2 at 56 or $72 \mathrm{~h}$ after PG; see Figure 1 for treatment definitions. Different letters $(\mathrm{a}, \mathrm{b})$ indicate that least squares treatment means differed $(P<0.05)$ at $72 \mathrm{~h}$. Color version available online.

\section{Postinsemination Events}

Neither number of post-TAI CL per cow nor total luteal tissue volume at $6 \mathrm{~d}$ post-TAI differed among treatment-time combinations. A tendency $(P=0.096)$ for a treatment $\times$ time interaction was detected, in which total luteal tissue volume in Pre10-72 cows was 53 to $70 \%$ of that assessed in the other treatments (Pre10-72 = $3.5 \pm 1.1 \mathrm{~cm}^{3}$; Pre10-56 = $6.6 \pm 1.0 \mathrm{~cm}^{3}$; PG-3-G-72 $=5.8 \pm 1.1 \mathrm{~cm}^{3}$; and PG-3-G-56 = 5.0 \pm $\left.1.21 \mathrm{~cm}^{3}\right)$.

Although the study was not designed to detect differences in P/AI, these same cows (Pre10-72) with numerically reduced post-AI luteal tissue volume tended $(P=$ $0.15)$ to have fewer pregnancies at $31 \mathrm{~d}$ post-AI than cows from other treatment-time combinations (Table 7). The 4 of 18 Pre10-72 cows that conceived each had a GnRH-induced LH surge and ovulated. Treatment differences at d 61 post-TAI followed a pattern similar to that at d 31. Pregnancy loss did not differ among treatment-time combinations, with only 1 pregnancy loss in the PG-3-G-72 treatment.

\section{DISCUSSION}

This study was designed to determine the incidence of spontaneous and predictable GnRH-induced LH surges and subsequent ovulation in lactating dairy cows enrolled in a TAI program preceded by presynchronization of estrous cycles. This objective was met by applying 2 presynchronization treatments, one of which (Pre10) should provide the greatest potential for ovulation in

Table 5. Incidence of LH surges and ovulation after GnRH-2

\begin{tabular}{|c|c|c|c|c|c|c|c|}
\hline \multirow{2}{*}{ Item } & \multicolumn{4}{|c|}{ Treatment $^{1}(\mathrm{~T})$} & & & \\
\hline & \multicolumn{2}{|c|}{ PG-3-G } & \multicolumn{2}{|c|}{ Pre10 } & \multicolumn{3}{|c|}{$P$-value } \\
\hline Progesterone $^{2}(\mathrm{ng} / \mathrm{mL})$ & \multicolumn{2}{|c|}{$0.3 \pm 0.2^{3}$} & \multicolumn{2}{|c|}{$0.4 \pm 0.2$} & 0.686 & - & - \\
\hline Progesterone $^{4}(\%)$ & \multicolumn{2}{|c|}{$97.0(32 / 33)^{5}$} & \multicolumn{2}{|c|}{$91.9(34 / 37)$} & 0.362 & - & - \\
\hline Follicle size ${ }^{6}(\mathrm{~mm})$ & \multicolumn{2}{|c|}{$13.6 \pm 0.5$} & \multicolumn{2}{|c|}{$13.5 \pm 0.5$} & 0.774 & - & - \\
\hline Spontaneous & $6.3(1 / 16)$ & $11.8(2 / 17)$ & $0(0 / 19)$ & $5.6(1 / 18)$ & 0.682 & 0.240 & 0.783 \\
\hline LH peak ${ }^{8}(\mathrm{ng} / \mathrm{mL})$ & $4.3 \pm 0.5$ & $4.9 \pm 0.5$ & $5.0 \pm 0.5$ & $4.8 \pm 0.5$ & 0.619 & 0.649 & 0.384 \\
\hline Time to LH peak ${ }^{9}(\mathrm{~h})$ & $1.7 \pm 0.2$ & $1.5 \pm 0.1$ & $1.5 \pm 0.1$ & $1.2 \pm 0.1$ & 0.114 & 0.124 & 0.608 \\
\hline Area under LH curve ${ }^{10}$ & $14.9 \pm 1.8$ & $17.8 \pm 1.7$ & $16.1 \pm 1.7$ & $14.8 \pm 1.7$ & 0.603 & 0.624 & 0.200 \\
\hline Ovulation $^{11}(\%)$ & $87.5(14 / 16)$ & $82.3(14 / 17)$ & $100(19 / 19)$ & $88.9(16 / 18)$ & 0.969 & 0.968 & 0.971 \\
\hline Double ovulation $^{11}(\%)$ & $12.5(2 / 16)$ & $11.8(2 / 17)$ & $5.3(1 / 19)$ & $11.1(2 / 18)$ & 0.673 & 0.797 & 0.489 \\
\hline
\end{tabular}

${ }^{1} \mathrm{PG}-3-\mathrm{G}=$ injection of $\mathrm{PGF}_{2 \alpha}$ (Pre-PG) administered at the same time as PG-2 followed in $3 \mathrm{~d}$ by Pre-GnRH injection, which was administered $7 \mathrm{~d}$ before onset of Ovsynch; Pre10 = 2 injections of $\mathrm{PGF}_{2 \alpha} 14 \mathrm{~d}$ apart (PG-1 and PG-2) with PG-2 administered $10 \mathrm{~d}$ before onset of Ovsynch. Cows were administered GnRH-2 at either 56 or 72 h after PG (see Figure 1).

${ }^{2}$ Progesterone concentrations at $60 \mathrm{~h}$ post-PG administration.

${ }^{3}$ Least squares means \pm SEM.

${ }^{4}$ Proportion of cows having progesterone concentrations $<0.5 \mathrm{ng} / \mathrm{mL}$ at $60 \mathrm{~h}$ post-PG-3.

${ }^{5} \%$ (no./no.).

${ }^{6}$ Determined at $48 \mathrm{~h}$ after PG-3.

${ }^{7}$ Increase in LH concentration greater than $2 \mathrm{SD}$ above baseline.

${ }^{8}$ Maximum LH concentration during 6 h after GnRH-2.

${ }^{9}$ Time to peak LH concentration during $6 \mathrm{~h}$ after GnRH-2.

${ }^{10}$ Calculated by the trapezoidal method.

${ }^{11}$ Single or multiple ovulation after GnRH-2. 
Table 6. Ovulatory response to GnRH-induced or spontaneous LH surge ${ }^{1}$ depending on concentrations of progesterone and presynchronization treatment

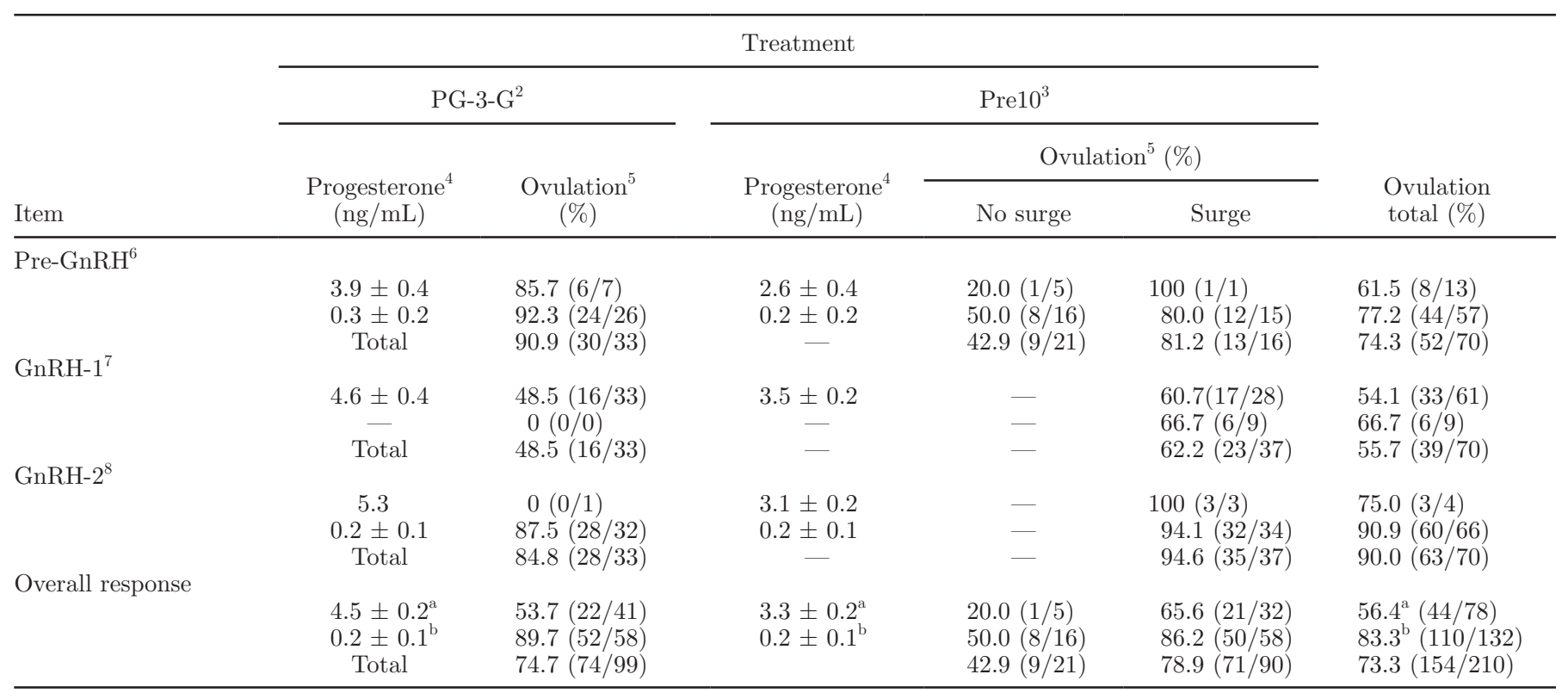

${ }^{\mathrm{a}, \mathrm{b}}$ Means within a column with different superscripts differ $(P<0.01)$.

${ }^{1}$ Increase in LH concentration (GnRH-induced or spontaneously occurring before, during, or after GnRH injection) greater than 2 SD above baseline during $6 \mathrm{~h}$ after $\mathrm{GnRH}$.

${ }^{2} \mathrm{PG}-3-\mathrm{G}=$ injection of $\mathrm{PGF}_{2 \mathrm{a}}$ administered at the same time as PG-2 followed in $3 \mathrm{~d}$ by Pre-GnRH injection, which was administered $7 \mathrm{~d}$ before onset of Ovsynch (see Figure 1). LH surges were detected in all PG-3-G cows.

${ }^{3}$ Pre10 $=2$ injections of PGF $_{2 \mathrm{a}} 14 \mathrm{~d}$ apart (PG-1 and PG-2) with PG-2 administered $10 \mathrm{~d}$ before onset of Ovsynch-56 (see Figure 1).

${ }^{4}$ Concentration of progesterone at the time of $\mathrm{GnRH}$ injection.

${ }^{5}$ Percentage of cows ovulating at least 1 follicle in response to LH surge.

${ }^{6}$ Pre-GnRH injection given 3 d after Pre-PG or no injection in Pre10 cows.

${ }^{7} \mathrm{GnRH}-1$ injection given at the onset of Ovsynch.

${ }^{8} \mathrm{GnRH}-2$ injection given at either 56 or $72 \mathrm{~h}$ after PG-3 (see Figure 1).

response to GnRH-1 of Ovsynch when PG-Presynch programs precede Ovsynch (Vasconcelos et al., 1999; Galvão et al., 2007). Perhaps equally as important as increasing ovulation response to GnRH of Ovsynch is producing greater concentrations of progesterone at the onset of Ovsynch, which also resulted in greater fertil-

Table 7. Pregnancy per AI after presynchronization with PG-3-G or Pre10 and GnRH-2 administration at 56 or $72 \mathrm{~h}$ after PG-3

\begin{tabular}{|c|c|c|c|c|}
\hline \multirow[b]{3}{*}{ Item } & \multicolumn{4}{|c|}{ Treatment $^{1}$} \\
\hline & \multicolumn{2}{|c|}{ PG-3-G } & \multicolumn{2}{|c|}{ Pre10 } \\
\hline & $56 \mathrm{~h}$ & $72 \mathrm{~h}$ & $56 \mathrm{~h}$ & $72 \mathrm{~h}$ \\
\hline \multicolumn{5}{|c|}{ Pregnancy per AI [\% (no./no.)] } \\
\hline At $31 \mathrm{~d}^{2}$ & $57.1(8 / 14)$ & $56.3(9 / 16)$ & $52.6(10 / 19)$ & $22.2(4 / 18)$ \\
\hline At $61 \mathrm{~d}^{3}$ & $57.1(8 / 14)$ & $50.0(8 / 16)$ & $52.6(10 / 19)$ & $22.2(4 / 18)$ \\
\hline Pregnancy $\operatorname{loss}^{4}(\%)$ & $0(0 / 8)$ & $11.1(1 / 9)$ & $0(0 / 10)$ & $0(0 / 4)$ \\
\hline \multicolumn{5}{|c|}{$\begin{array}{l}{ }^{1} \mathrm{PG}-3-\mathrm{G}=\text { injection of } \mathrm{PGF}_{2 \alpha}(\mathrm{Pre}-\mathrm{PG}) \text { administered at the same time as PG-2 followed in } 3 \mathrm{~d} \text { by Pre-GnRF } \\
\text { injection, which was administered } 7 \mathrm{~d} \text { before onset of Ovsynch; Pre } 10=2 \text { injections of } \mathrm{PGF}_{2 \alpha} 14 \mathrm{~d} \text { apart }(\mathrm{PG}-1 \\
\text { and } \mathrm{PG}-2) \text { with } \mathrm{PG}-2 \text { administered } 10 \mathrm{~d} \text { before onset of Ovsynch. Cows were administered } \mathrm{GnRH}-2 \text { at eithe } \\
56 \text { or } 72 \mathrm{~h} \text { after } \mathrm{PG} \text { (see Figure } 1) \text {. Three PG-3-G cows were culled before pregnancy diagnosis. } \\
{ }^{2} \text { Treatment }(P=0.072) \text {, time }(P=0.192) \text {, and treatment } \times \text { time }(P=0.153) \text {. } \\
{ }^{3} \text { Treatment }(P=0.104) \text {, time }(P=0.115) \text {, and treatment } \times \text { time }(P=0.230) .\end{array}$} \\
\hline
\end{tabular}


ity (Stevenson et al., 2012; Ayres et al., 2013). Thus, PG-3-G was chosen as the second presynchronization treatment (Stevenson et al., 2012).

Improving the ovulatory response to $\mathrm{GnRH}-1$ results in better embryo quality (Cerri et al., 2009) and increased P/AI (Chebel et al., 2006; Stevenson et al., 2007; Rutigliano et al., 2008). The PG-3-G treatment was chosen because of its potential to stimulate ovulation in cows before commencement of a TAI protocol (Bello et al., 2006; Souza et al., 2008), particularly in anovular cows (Stevenson et al., 2012). The novel findings of the present study are the characteristics of LH release associated with each GnRH injection in a presynchronization-Ovsynch program and subsequently documented ovulation in 210 possible cases.

Incidence of spontaneous LH surges was greater in Pre10 than in PG-3-G cows receiving the Pre-GnRH injection. Consequently, Pre10-treated cows had lesser LH peak concentrations during the 6 -h window $72 \mathrm{~h}$ after PG-2 compared with the induced LH surge peak concentrations in PG-3-G treated cows. Spontaneous LH surges in control cows occurred from 52 to $104 \mathrm{~h}$ after PG injection, whereas in cows administered $\mathrm{GnRH}$ at $72 \mathrm{~h}$ after $\mathrm{PG}$, induced $\mathrm{LH}$ surges occurred between 74.2 and $74.5 \mathrm{~h}$ (Lucy and Stevenson, 1986). The findings of current study confirm this earlier report.

Incidence of ovulation after Pre-GnRH was 91\% for PG-3-G and $60 \%$ for Pre10 cows. Previous studies reported ovulation incidence of 80 and $85 \%$, which is similar to the $91 \%$ of the current study, following the Pre-GnRH injection in the same (Stevenson et al., 2012) or similar treatments (G-6-G; GnRH injection was administered $2 \mathrm{~d}$ after a PG injection; Bello et al., 2006). Seven days after the Pre-GnRH injection, progesterone concentrations were greater in $\mathrm{PG}-3-\mathrm{G}$ than in Pre10 cows because more PG-3-G cows ovulated in response to Pre-GnRH.

At GnRH-1, the proportion of cows with progesterone concentrations $\geq 1 \mathrm{ng} / \mathrm{mL}$, the number of CL per cow, and the proportion of cows having a CL were greater in PG-3-G cows than in Pre10 cows, confirming our earlier findings utilizing the same treatment and control (Stevenson et al., 2012). Progesterone concentrations $>3 \mathrm{ng} / \mathrm{mL}$ in cows presynchronized with Double Ovsynch $7 \mathrm{~d}$ after $\mathrm{GnRH}$-induced ovulation (Souza et al., 2008; Giordano et al., 2012) or Presynch-Ovsynch (Moreira et al., 2001; Stevenson et al., 2012) have been reported in several studies, and the current study corroborates these previous results. More PG-3-G cows had progesterone concentrations $\geq 1 \mathrm{ng} / \mathrm{mL}$ (100 vs. $80 \%$ ) compared with Pre10 cows, which is similar to our previous report for the same treatments (90.5 vs. 76.2\%; Stevenson et al., 2012). Likewise, the number of CL per cow and the proportion of cows with a CL were greater in PG-3-G cows than in Pre10 cows in the current study and in our recent report (Stevenson et al., 2012).

All cows regardless of treatment had induced $\mathrm{LH}$ surges after GnRH-1. Time to peak LH concentration was $0.7 \mathrm{~h}$ earlier for PG-3-G compared with Pre10 cows, but LH peak concentration and area under the LH curve was greater in Pre10 than in PG-3-G cows. Ovulation incidence did not differ between treatments, ranging from 48 to $62 \%$, which is consistent with our previous findings (Stevenson et al., 2012) and is similar to another report of ovulation incidence of $55 \% 7 \mathrm{~d}$ after a prior GnRH injection (Souza et al., 2009).

Giordano et al. (2012) reported that peak LH concentrations and the area under the LH curve were greater in 12 cows with low $(<1 \mathrm{ng} / \mathrm{mL})$ progesterone than in 12 cows with high $(>1 \mathrm{ng} / \mathrm{mL})$ progesterone concentrations. In the present study, progesterone concentrations, proportions of cows with progesterone $\geq 1 \mathrm{ng} / \mathrm{mL}$, number of CL per cow, and proportions of cows with a CL were less in Pre10 cows than in PG-3-G cows, which explains why peak LH concentrations were greater in Pre10 than in PG-3-G cows after GnRH-1. Not only were the concentration of $\mathrm{LH}$ and the incidence of $\mathrm{LH}$ surges reduced in the presence of greater progesterone concentrations, but the incidence of ovulation was also suppressed. The pituitary gland exhibits attenuation in its response to exogenous GnRH treatment in the presence of high circulating concentrations of progesterone (Schoenemann et al., 1985). Similar findings have been reported in beef heifers (Dias et al., 2010) and beef cows (Cline, 2002; Colazo et al., 2008). Area under the LH curve was greater in Pre10 cows with lower progesterone concentrations in the present study than in PG-3-G cows having greater progesterone concentrations. Area under the LH curve $\left(39.9 \pm 4.5 \mathrm{ng}^{2}\right)$ after using the same gonadorelin product $7 \mathrm{~d}$ after a previous GnRH injection in lactating dairy cows (Souza et al., 2009) was reported to be greater than that detected in the current study after GnRH-2 (7.62 \pm 1.97 to $10.56 \pm$ $4.94 \mathrm{ng}^{2}$ ). Despite the lesser LH concentrations secreted in response to GnRH-1 than those previously reported, follicle diameter and ovulation rates after GnRH-1 administration did not differ between treatments, and incidence of double ovulation was similar.

Immediately before PG-3, progesterone and estradiol concentrations, the proportion of cows with progesterone concentrations $\geq 1 \mathrm{ng} / \mathrm{mL}$, the number of CL per cow, and follicle diameter did not differ between treatments. In our previous study of these same presynchronization treatments, we reported that PG-3-G tended to increase the proportion of cows with progesterone concentrations $\geq 1 \mathrm{ng} / \mathrm{mL}$ and increased the number of CL per cow (Stevenson et al., 2012). In the present 
study, with fewer cows, we were unable to detect any of the previously reported differences at PG-3, except for the increased proportion of cows with a CL in PG-3-G cows.

To control timing of the LH surge and ovulation, the final $\mathrm{GnRH}$ injection should be given before a spontaneous LH surge for TAI to result in pregnancy outcomes similar to breeding based on detected estrus (Peters and Pursley, 2002). Studies have indicated that the earliest a spontaneous LH surge occurs is 36 to $48 \mathrm{~h}$ following PG-induced luteal regression (Twagiramungu et al., 1992; Walker et al., 1996). In the present study, only 1 cow had a spontaneous surge before GnRH was given at $56 \mathrm{~h}$, whereas 3 cows had spontaneous $\mathrm{LH}$ surges before GnRH was administered at $72 \mathrm{~h}$, likely producing less synchrony between AI and ovulation. No other LH characteristics differed between treatmenttime combinations after GnRH-2, including incidence of ovulation.

In the current study, LH peak concentrations in response to GnRH treatments ranged from 2.19 to 5.24 $\mathrm{ng} / \mathrm{mL}$. These peak concentrations are similar to those reported by Lucy and Stevenson (1986), with LH peak concentration ranging from 0.6 to $6.7 \mathrm{ng} / \mathrm{mL}$ in dairy cows. In contrast, Souza et al. (2009) reported LH peak concentration in response to $50 \mu \mathrm{g}$ of $\mathrm{GnRH}$ of $9.6 \mathrm{ng} /$ $\mathrm{mL}$ and $21.6 \mathrm{ng} / \mathrm{mL}$ after $100 \mu \mathrm{g}$ of $\mathrm{GnRH}$ in lactating dairy cows. Most of these differences are likely related to using different LH standards, GnRH products (Souza et al., 2009), and frequencies of blood sample collection.

At $72 \mathrm{~h}$, estradiol concentrations were greater for PG-3-G cows than Pre10 cows. Previously reported maximal estradiol concentrations before ovulation in lactating dairy cows were $7.3 \pm 0.8 \mathrm{pg} / \mathrm{mL}$ (Sartori et al., 2004) and $7.9 \pm 0.8 \mathrm{pg} / \mathrm{mL}$ (Wiltbank et al., 2006). Cows receiving GnRH-2 at $72 \mathrm{~h}$ had an additional 16 $\mathrm{h}$ for follicular maturation and estradiol production and, because most cows had not been exposed to an LH surge, estradiol production increased unattenuated (Wiltbank and Pursley, 2014). In response to the LH surge, the original source of elevated estradiol, the preovulatory follicle begins to undergo changes that result in reduced estradiol production, breakdown of the basement membrane, and reinitiation of meiosis in the oocyte before ovulation occurs after a delay of approximately $28 \mathrm{~h}$ in the cow (Wiltbank and Pursley, 2014). Additional increases in concentrations of estradiol in plasma resulted in more cows in estrus at AI (Hillegass et al., 2008), which has been linked with improved fertility of cows in TAI programs (Santos et al., 2010). Cows with estradiol concentrations $\geq 2$ $\mathrm{pg} / \mathrm{mL}$ also had an increased presence of uterine fluid at $48 \mathrm{~h}$ after PG-3 compared with cows having lesser estradiol concentrations, perhaps facilitating improved uterine and oviductal transport of sperm (Hawk, 1987).

Pregnancy per AI at $31 \mathrm{~d}$ postinsemination was numerically lower in cows receiving the Pre10-72 treatment compared with other treatment-time permutations. We previously reported that $\mathrm{P} / \mathrm{AI}$ was numerically greater in PG-3-G (40\%) cows than in Pre10 (33.3\%) cows at d 32 when GnRH was given $56 \mathrm{~h}$ after PG (Stevenson et al., 2012). Although consistent in direction, both studies lacked sufficient power to detect differences in $\mathrm{P} / \mathrm{AI}$. In the current study, $\mathrm{P} / \mathrm{AI}$ tended to differ for PG-3-G (56.7\%) compared with Pre10 (37.8\%) and for $56 \mathrm{~h}(54.5 \%)$ compared with $72 \mathrm{~h}(38.2 \%)$, with $\mathrm{P} /$ $\mathrm{AI}$ in the Pre10-72 $\mathrm{h}$ treatment combination producing less than half $(22.2 \%)$ the pregnancies compared with all other treatment combinations. Furthermore, in these same cows, post-TAI luteal tissue volume tended to be compromised. In another study investigating the same presynchronization treatments in 4 commercial dairy herds, we reported that $\mathrm{P} / \mathrm{AI}$ was numerically increased in 1,286 PG-3-G-treated cows (41.2\%) compared with 1,247 Pre10 cows (35\%) at d 32 to 38 (Stevenson and Pulley, 2012). During the summer, cows presynchronized with PG-3-G had greater P/AI than Pre10 cows, but the results did not differ during nonsummer seasons (Stevenson and Pulley, 2012).

Adaptations to the Ovsynch protocol, such as the timing of the final $\mathrm{GnRH}$ administration at $56 \mathrm{~h}$ after the PG injection to optimize the timing of $\mathrm{AI}$ in relation to ovulation, which occurs approximately 24 to 32 $\mathrm{h}$ after $\mathrm{GnRH}$, may explain the improved $\mathrm{P} / \mathrm{AI}$ in the present study as well as in other reports (Pursley et al., 1998; Brusveen et al., 2008; Wiltbank and Pursley, 2014). Cows receiving the combination of Pre10 and GnRH-2 administered at $72 \mathrm{~h}$ had increased incidence of spontaneous LH surges before GnRH-2. Insemination near or after ovulation may provide insufficient time for sperm capacitation and transport in the reproductive tract, resulting in aged oocytes before fertilization (Hunter and Wilmut, 1983; Wilmut and Hunter, 1984; Hawk, 1987). A 4-h interval between AI and anticipated ovulation may be insufficient for sperm transport and before postovulatory oocyte aging (Brusveen et al., 2008). Despite these reports, many dairies utilize the Cosynch-72 protocol, in which the final GnRH injection is given concurrently with TAI at $72 \mathrm{~h}$ after PG because it eliminates one cow-handling period and facilitates once-daily restraint of cows for administration of hormone injections for TAI (Sterry et al., 2007).

Studies have compared Cosynch to Ovsynch with conflicting P/AI results (DeJarnette and Marshall, 2003; Portaluppi and Stevenson, 2005; Cornwell et al., 2006; Brusveen et al., 2008). Reports by Brusveen et 
al. (2008) of increased first-service and repeat-service $\mathrm{P} / \mathrm{AI}$ in cows receiving Ovsynch-56 compared with Cosynch-72 are consistent with the present study. Brusveen et al. (2008) attributed the differences in P/ AI to the timing of the final $\mathrm{GnRH}$ injection because time of AI did not differ among treatments. Another study reported no difference in $\mathrm{P} / \mathrm{AI}$ at $30 \mathrm{~d}$ in grazing dairy cows treated with either Double Ovsynch or Presynch-10 when assigned to a 5-d Cosynch with the final GnRH and TAI administered at either 58 or 72 h (Ribeiro et al., 2012). Delayed interval between the second GnRH injection and AI is likely to optimize P/ $\mathrm{AI}$ in ovulation-synchronization protocols (DeJarnette and Marshall, 2003). The PG-3-G treatment seems to be more flexible in terms of $\mathrm{GnRH}$ administration timing, because $\mathrm{P} / \mathrm{AI}$ did not differ regardless of when GnRH administration occurred (56 or $72 \mathrm{~h}$ ) in the present study.

In summary, presynchronization using the PG-3-G protocol increased the proportion of cows having $\mathrm{LH}$ surges and ovulation incidence after Pre-GnRH. Incidence of LH surges after GnRH-1 did not differ because all cows had an LH surge regardless of treatment; however, Pre10 cows had greater LH peak concentrations and area under the curve for LH compared with PG$3-\mathrm{G}$ in the face of lower progesterone concentrations than was detected in PG-3-G cows. Overall, greater progesterone concentrations reduced the incidence of LH surges and ovulation. At GnRH-2, treatments did not differ in ovulation incidence, incidence of induced LH surges, LH peak concentrations, or area under the LH curve. Although 100\% of cows had either spontaneous or GnRH-induced LH surges after GnRH-2, 10\% of those cows failed to ovulate even though all but one cow had concentrations of progesterone averaging 0.2 $\mathrm{ng} / \mathrm{mL}$. Documenting the cause of this ovulation failure warrants further study. Administration of GnRH-2 at $72 \mathrm{~h}$ tended to decrease time to peak LH concentration and increase incidence of spontaneous LH surges compared with GnRH at $56 \mathrm{~h}$. Pregnancy per AI at $31 \mathrm{~d}$ postinsemination seemed to be lower in cows receiving the Pre10-72 treatment compared with those receiving Pre10-56, PG-3-G-56, or PG-3-G-72 treatments.

\section{CONCLUSIONS}

We conclude that PG-3-G increased progesterone concentrations and the number of CL before GnRH-1 (onset of Ovsynch), thus decreasing LH peak concentrations. Concentrations of LH, incidence of LH surges, and ovulation were suppressed when progesterone was elevated. Delaying GnRH-2 administration to $72 \mathrm{~h}$ after PG-3 may increase the incidence of spontaneous LH surges and reduce P/AI in cows receiving Pre10-72 treatment compared with Pre10-56, PG-3-G-56, or PG-3G-72. The PG-3-G treatment may be more forgiving for the timing of GnRH administration before TAI because $\mathrm{P} / \mathrm{AI}$ was similar regardless of when $\mathrm{GnRH}$ administration occurred (56 or $72 \mathrm{~h}$ ) in the present study.

\section{REFERENCES}

Atkins, J. A., D. C. Busch. J. F. Bader, D. H. Keisler, D. J. Patterson, M. C. Lucy, and M. F. Smith. 2008. Gonadotropin-releasing hormone induced ovulation and luteinizing hormone release in beef heifers: Effect of day of the cycle. J. Anim. Sci. 86:83-93.

Ayres, H., R. M. Ferreira, A. P. Cunha, R. R. Araujo, and M. C. Wiltbank. 2013. Double-Ovsynch in high-producing dairy cows: Effects on progesterone concentrations and ovulation to $\mathrm{GnRH}$ treatments. Theriogenology 79:159-164.

Bello, N. M., J. P. Steibel, and J. R. Pursley. 2006. Optimizing ovulation to first GnRH improved outcomes to each hormonal injection of Ovsynch in lactating dairy cows. J. Dairy Sci. 89:3413-3424.

Brusveen, D. J., A. P. Cunha, C. D. Silva, P. M. Cunha, R. A. Sterry, E. P. B. Silva, J. N. Guenther, and M. C. Wiltbank. 2008. Altering the time of the second gonadotropin-releasing hormone injection and artificial insemination (AI) during Ovsynch affects pregnancies per AI in lactating dairy cows. J. Dairy Sci. 91:1044-1052.

Caraviello, D. Z., K. A. Weigel, P. M. Fricke, M. C. Wiltbank, M J. Florent, N. B. Cook, K. V. Nordlund, N. R. Zwald, and C. L. Rawson. 2006. Survey of management practices on reproductive performance of dairy cattle on large U. S. commercial farms. J. Dairy Sci. 89:4723-4735.

Cerri, R. L. A., H. M. Rutigliano, R. G. S. Bruno, and J. E. P. Santos. 2009. Progesterone concentrations, follicular development, and induction of cyclicity in dairy cows receiving intravaginal progesterone inserts. Anim. Reprod. Sci. 110:56-70.

Chebel, R. C., J. E. P. Santos, R. L. A. Cerri, H. M. Rutigliano, and R. G. S. Bruno. 2006. Reproduction in dairy cows following progesterone inserts presynchronization and resynchronization protocols. J. Dairy Sci. 89:4205-4219.

Cline, M. A. 2002. Efficacy of synthetic gonadotropin releasing hormone analogs for control of ovulation during estrus synchronization protocols. MS Thesis. Virginia Polytechnic Institute and State University, Blacksburg.

Colazo, M. G., J. P. Kastelic, H. Davis, M. D. Rutledge, M. F. Martinez, J. A. Small, and R. J. Mapletoft. 2008. Effect of plasma progesterone concentrations on LH release and ovulation in beef cattle given GnRH. Domest. Anim. Endocrinol. 34:109-117.

Cornwell, J. M., M. L. McGilliard, R. Kasimanickam, and R. L. Nebel. 2006. Effect of sire fertility and timing of artificial insemination in a Presynch + Ovsynch protocol on first-service pregnancy rates. J. Dairy Sci. 89:2473-2478

DeJarnette, J. M., and C. E. Marshall. 2003. Effects of pre-synchronization using combinations $\mathrm{PGF}_{2 \alpha}$ and (or) GnRH on pregnancy rates of Ovsynch- and Cosynch-treated lactating Holstein cows. Anim. Reprod. Sci. 77:51-60.

Dias, F. C., M. G. Colazo, J. P. Kastelic, R. J. Mapletoft, G. P. Adams, and J. Singh. 2010. Progesterone concentration, estradiol pretreatment, and dose of gonadotropin-releasing hormone-mediated luteinizing hormone release in beef heifers. Domest. Anim. Endocrinol. 39:155-162.

El-Zarkouny, S. Z., J. A. Cartmill, B. A. Hensley, and J. S. Stevenson. 2004. Pregnancy in dairy cows after synchronized ovulation regimens with or without presynchronization and progesterone. J. Dairy Sci. 87:1024-1037.

Ferguson, J. D., D. T. Galligan, and N. Thomsen. 1994. Principal descriptors of body condition score in Holstein cows. J. Dairy Sci. 77:2695-2703.

Galvão, K. N., M. F. Sá Filho, and J. E. P. Santos. 2007. Reducing the interval from presynchronization to initiation of timed artificial insemination improves fertility in dairy cows. J. Dairy Sci. 90:4212-4218. 
Giordano, J. O., P. M. Fricke, J. N. Guenther, G. Lopes Jr., M. M. Herlihy, A. B. Nascimento, and M. C. Wiltbank. 2012. Effect of progesterone on magnitude of the luteinizing hormone surge induced by two different doses of gonadotropin-releasing hormone in lactating dairy cows. J. Dairy Sci. 95:3781-3793.

Hawk, H. W. 1987. Transport and fate of spermatozoa after insemination of cattle. J. Dairy Sci. 70:1487-1503.

Herlihy, M. M., J. O. Giordano, A. H. Souza, H. Ayres, R. M. Ferreira, A. Keskin, A. B. Nascimento, J. N. Guenther, J. M. Gaska, S. J. Kacuba, M. A. Crowe, S. T. Butler, and M. C. Wiltbank. 2012. Presynchronization with Double-Ovsynch improves fertility at first postpartum artificial insemination in lactating dairy cows. J. Dairy Sci. 95:7003-7014.

Hillegass, J., F. S. Lima, M. F. Sá Filho, and J. E. P. Santos. 2008. Effect of time of artificial insemination and supplemental estradiol on reproduction of lactating dairy cows. J. Dairy Sci. 91:4226-4237.

Hunter, R. H. F., and I. Wilmut. 1983. The rate of functional sperm transport into the oviducts of mated cows. Anim. Reprod. Sci. $5: 167-173$.

Lucy, M. C., and J. S. Stevenson. 1986. Gonadotropin-releasing hormone at estrus: Luteinizing hormone, estradiol, and progesterone during the periestrual and postinsemination periods in dairy cattle. Biol. Reprod. 35:300-311.

Martinez, M. F., R. J. Mapletoft, J. P. Kastelic, and T. Carruthers. 2003. The effects of 3 gonadorelin products on luteinizing hormone release, ovulation, and follicular wave emergence in cattle. Can. Vet. J. 44:125-131.

Moeller, L. M., N. A. Michael, J. C. Dalton, and G. C. Lamb. 2010. Evaluating reproductive outcomes in United States Holstein dairies. J. Dairy Sci. 93(E-Suppl. 1):408. (Abstr.)

Moreira, F., C. Orlandi, C. A. Risco, R. Mattos, F. Lopes, and W. W. Thatcher. 2001. Effects of presynchronization and bovine somatotropin on pregnancy rates to a timed artificial insemination protocol in lactating dairy cows. J. Dairy Sci. 84:1646-1659.

Navanukraw, C., D. A. Redmer, L. P. Reynolds, J. D. Kirsch, A. T. Grazul-Bilska, and P. M. Fricke. 2004. A modified presynchronization protocol improves fertility to timed artificial insemination in lactating dairy cows. J. Dairy Sci. 87:1551-1557.

NRC. 2001. Nutrient Requirements of Dairy Cattle. 7th rev. ed. Natl. Acad. Sci., Washington, DC.

Peters, M. W., and J. R. Pursley. 2002. Fertility of lactating dairy cows treated with Ovsynch after presynchronization injections of $\mathrm{PGF}_{2 \alpha}$ and GnRH. J. Dairy Sci. 85:2403-2406.

Portaluppi, M. A., and J. S. Stevenson. 2005. Pregnancy rates in lactating dairy cows after presynchronization of estrous cycles and variations of the Ovsynch protocol. J. Dairy Sci. 88:914-921.

Pursley, J. R., R. W. Silcox, and M. C. Wiltbank. 1998. Effect of time of artificial insemination on pregnancy rates, calving rates, pregnancy loss, and gender ratio after synchronization of ovulation in lactating dairy cows. J. Dairy Sci. 81:2139-2144.

Ribeiro, E. S., R. L. A. Cerri, R. S. Bisinotto, F. S. Lima, F. T. Silvestre, L. F. Greco, W. W. Thatcher, and J. E. P. Santos. 2011. Reproductive performance of grazing dairy cows following presynchronization and resynchronization protocols. J. Dairy Sci. 94:4984-4996.

Ribeiro, E. S., A. P. A. Monteiro, F. S. Lima, H. Ayres, R. S. Bisinotto, M. Favoreto, L. F. Greco, R. S. Marsola, W. W. Thatcher, and J. E. P. Santos. 2012. Effects of presynchronization and length of proestrus on fertility of grazing dairy cows subjected to a 5-day timed artificial insemination protocol. J. Dairy Sci. 95:2513-2522.

Rutigliano, H. M., F. S. Lima, R. L. A. Cerri, L. F. Greco, J. M. Vilela, V. Magalhaes, F. T. Silvestre, W. W. Thatcher, and J. E. P. Santos. 2008. Effects of method of presynchronization and source of selenium on uterine health and reproduction in dairy cows. J. Dairy Sci. 91:3323-3336.
Santos, J. E. P., C. D. Narciso, F. Rivera, W. W. Thatcher, and R. C. Chebel. 2010. Effect of reducing the period of follicle dominance in a timed AI protocol on reproduction of dairy cows. J. Dairy Sci. 93:2976-2988

Sartori, R., J. M. Haughian, R. D. Shaver, G. J. M. Rosa, and M. C. Wiltbank. 2004. Comparison of ovarian function and circulating steroids in estrous cycles of Holstein heifers and lactating cows. J. Dairy Sci. 87:905-920.

Schoenemann, H. M., W. D. Humphrey, M. E. Crowder, T. M. Nett, and J. J. Reeves. 1985. Pituitary luteinizing hormone-releasing hormone receptors in ovariectomized cows after challenge with ovarian steroids. Biol. Reprod. 32:574-583.

Souza, A. H., H. Ayres, R. M. Ferreira, and M. C. Wiltbank. 2008. A new presynchronization system (Double-Ovsynch) increases fertility at first postpartum timed AI in lactating dairy cows. Theriogenology 70:208-215.

Souza, A. H., A. P. Cunha, E. P. B. Silva, A. Gumen, H. Ayres, J. N. Guenther, and M. C. Wiltbank. 2009. Comparison of gonadorelin products in lactating dairy cows: Efficacy based on induced of ovulation of an accessory follicle and circulating luteinizing hormone profiles. Theriogenology 72:271-279.

Sterry, R. A., P. W. Jardon, and P. M. Fricke. 2007. Effect of timing of Cosynch on fertility of lactating Holstein cows after first postpartum and Resynch timed-AI services. Theriogenology 67:12111216.

Stevenson, J. S. 2011. Alternative programs to presynchronize estrous cycles in dairy cattle before a timed artificial insemination program . J. Dairy Sci. 94:205-217.

Stevenson, J. S., M. A. Portaluppi, and D. E. Tenhouse. 2007. Factors influencing upfront single and multiple-ovulation incidence, progesterone, and luteolysis before a timed insemination resynchronization protocol. J. Dairy Sci. 90:5542-5551.

Stevenson, J. S., and S. L. Pulley. 2012. Pregnancy per artificial insemination after presynchronizing estrous cycles with the Presynch-10 protocol or prostaglandin $\mathrm{F}_{2 \alpha}$ injection followed by gonadotropinreleasing hormone before Ovsynch-56 in 4 dairy herds of lactating dairy cows. J. Dairy Sci. 95:6513-6522.

Stevenson, J. S., S. L. Pulley, and H. I. Mellieon Jr.. 2012. Prostaglandin $\mathrm{F}_{2 \alpha}$ and gonadotropin-releasing hormone administration improve progesterone status, luteal number, and proportion of ovular and anovular dairy cows with corpora lutea before a timed artificial insemination program. J. Dairy Sci. 95:1831-1844.

Twagiramungu, H., L. A. Guilbault, J. Proulx, P. Villeneuve, and J. J. Dufour. 1992. Influence of an agonist of gonadotropin-releasing hormone (buserelin) on estrus synchronization and fertility in beef cows. J. Anim. Sci. 70:1904-1910.

Vasconcelos, J. L. M., R. W. Silcox, G. L. M. Rosa, J. R. Pursley, and M. C. Wiltbank. 1999. Synchronization rate, size of the ovulatory follicle, and pregnancy rate after synchronization of ovulation beginning on different days of the estrous cycle in lactating dairy cows. Theriogenology 52:1067-1078.

Walker, W. L., R. L. Nebel, and M. L. McGilliard. 1996. Time of ovulation relative to mounting activity in dairy cattle. J. Dairy Sci. 79:1555-1561.

Wilmut, I., and R. H. Hunter. 1984. Sperm transport into the oviducts of heifers mated early in oestrus. Reprod. Nutr. Dev. 24:461-468.

Wiltbank, M. C., H. Lopez, R. Sartori, S. Sangsritavong, and A. Gumen. 2006. Changes in reproductive physiology of lactating dairy cows due to elevated steroid metabolism. Theriogenology 65:1729.

Wiltbank, M. C., and J. R. Pursley. 2014. The cow as an induced ovulator: Timed AI after synchronization of ovulation. Theriogenology 81:170-185. 